\title{
MORFOMETRI GISIK KAWASAN PANTAI WISATA BAHARI SARIO KOTA MANADO
}

\author{
(Beach Morphology in Wisata Bahari Sario Kota Manado Coastal Area) \\ Zulkifli Otoluwa ${ }^{*}$, Rignolda Djamaluddin ${ }^{1}$, Royke M. Rampengan ${ }^{1}$, Jane M. \\ Mamuaja ${ }^{1}$, Esry T. Opa ${ }^{1}$, Joudy R.R. Sangari ${ }^{2}$ \\ ${ }^{1}$ Program Studi IImu Kelautan FPIK UNSRAT Manado \\ 2Jurusan MSP UNSRAT Manado \\ *e-mail: Zulkifliotoluwa20@gmail.com
}

\begin{abstract}
Beach formation has an important role in protecting land from the action of the sea and it is useful for recreation, conservation and other uses. In "Wisata Bahari Sario" Kota Manado coastal area there is still a particular area of beach that is used for various purposes, so it is important to study its morphology. This research was conducted with the aim of describing morphology and analyzing oceanographic factors that affected the dynamic process of beach morphology. The results showed that the beach had an area of $422.69 \mathrm{~m} 2$, with the criteria for short slopes in the Northeast and long slopes in the Southwest. The shapes of the beach surface were in the form of gutters and shoots, their appearance was more visible towards the Southwest. In general, the deposition process took place more intensively in the Southwestern part of the beach.
\end{abstract}

Keywords: Beach, Morphology, Slope, Deposition

\begin{abstract}
Abstrak
Lahan gisik memiliki peran penting melindungi daratan dari aksi laut selain bermanfaat untuk tempat rekreasi, konservasi dan pemanfaatan lainnya. Di kawasan Wisata Bahari Sario Kota Manado masih terdapat lahan gisik yang dimanfaatkan untuk berbagai kepentingan sehingga penting untuk ditelaah morfologi lahan tersebut. Penelitian ini dilakukan dengan tujuan mendeskripsikan morfologi dan menganalisis faktor-faktor oseanografi yang mempengaruhi proses dinamika morfologi lahan. Hasil penelitian menunjukkan bahwa lahan gisik memiliki luas 422,69 $\mathrm{m}^{2}$, terkriteria lereng pendek di bagian Timur Laut dan lereng Panjang di bagian Barat Daya. Bentuk permukaan lahan gisik berupa serokan dan rabung, tampilannya lebih nampak semakin ke arah Barat Daya. Secara umum, proses deposisi berlangsung lebih intensif pada bagian lahan sebelah Barat Daya.
\end{abstract}

Kata kunci : Gisik, Morfologi, Lereng, Deposisi 


\section{PENDAHULUAN}

Gisik adalah salah satu ruang alami di kawasan pantai yang ciri utamanya tersusun atas material lepas. Letaknya berada antara jangkauan aksi gelombang saat pasang tertinggi dan jangkauan aksi gelombang saat surut terendah (Gross, 1993). Sumber material lahan gisik sekitar $90 \%$ berasal dari daratan dan pembentukannya diperankan oleh faktor gelombang, arus dekat pantai, dan pasang surut (Pethick (1997).

Keberadaan gisik menghadirkan banyak keuntungan yang tercermin pada fungsi dan manfaat lahan tersebut. Salah satu fungsi utama gisik adalah melindungi daratan dari aksi laut terutama gelombang dan arus (Gross, 1993). Gisik dapat dimanfaatkan sebagai tempat rekreasi dan juga sebagai daerah konservasi (Williams dan Micallef, 2009).

Berbagai fungsi dan manfaat yang ditawarkan lahan gisik sering memicu adanya konflik kepentingan dalam pemanfaatannya (Williams dan Micallef, 2009). Oleh karena itu, penataan ruang dan pengelolaannya perlu diatur secara tepat dengan memperhatikan berbagai kepentingan yang ada, dan dengan memperhatikan kondisi fisik dan dinamika lahan berdasarkan kajian ilmiah.

Secara aktual, pantai Sario Kota Manado sebagian besar sudah ditimbun untuk pembangunan infrastruktur penunjang ekonomi. Walaupun demikian masih terdapat ruang terbuka yang masih menghadirkan lahan gisik di kawasan pantai ini. Keberadaan lahan gisik ini menarik ditelaah untuk menunjang pemanfaatannya secara optimal. Berkaitan dengan itu, penelitian ini dilakukan dengan tujuan mendeskripsikan morfologi gisik di tempat ini serta menganalisis faktor-faktor oseanografi yang mempengaruhi dinamikanya. Hasil penelitian berupa peta relief/kontur permukaan lahan gisik dan kemiringan lereng diharapkan dapat berguna untuk menunjang pemanfaatan lahan yang ditelaah secara berkelanjutan dan dapat berguna bagi observasi yang sama di masa akan dating.

\section{METODE PENELITIAN}

\section{Lokasi Penelitian}

Lokasi penelitian terletak di kawasan pantai Wisata Bahari, Kelurahan Sario Tumpaan, Kecamatan Sario, Kota Manado, Provinsi Sulawesi Utara. Lokasi yang berada di pesisir Teluk Manado ini diapit oleh keberadaan lahan reklamasi seperti yang diperlihatkan dalam Gambar 1.

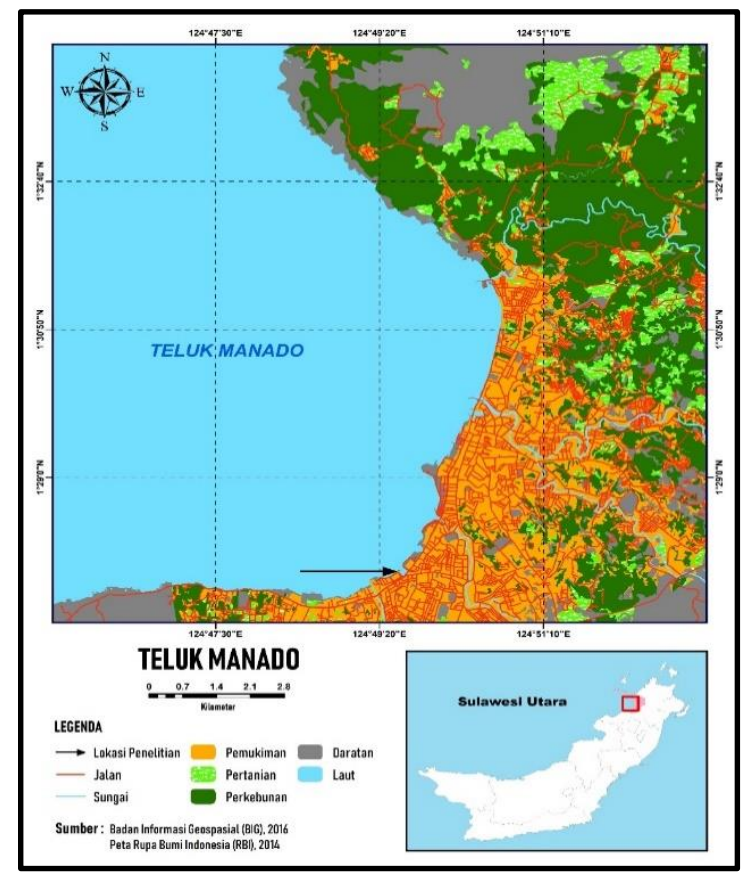

Gambar 1. Peta Lokasi Penelitian di Kawasan Pantai Wisata Bahari, Teluk Manado.

\section{Observasi dan Pengumpulan Data}

Dalam rangka menunjang kegiatan penyusunan hasil penelitian, telah dilakukan observasi pendahuluan pada tanggal 27 Januari 2020 untuk 
memperoleh suatu gambaran umum tentang keadaan gisik. Observasi yang dimaksud meliputi kegiatan pengukuran terinci terhadap kawasan studi dengan bantuan citra Google Earth dan GPS. Hasil observasi pendahuluan disusun dalam bentuk sketsa lokasi penelitian seperti yang ditampilkan pada Gambar 2 .

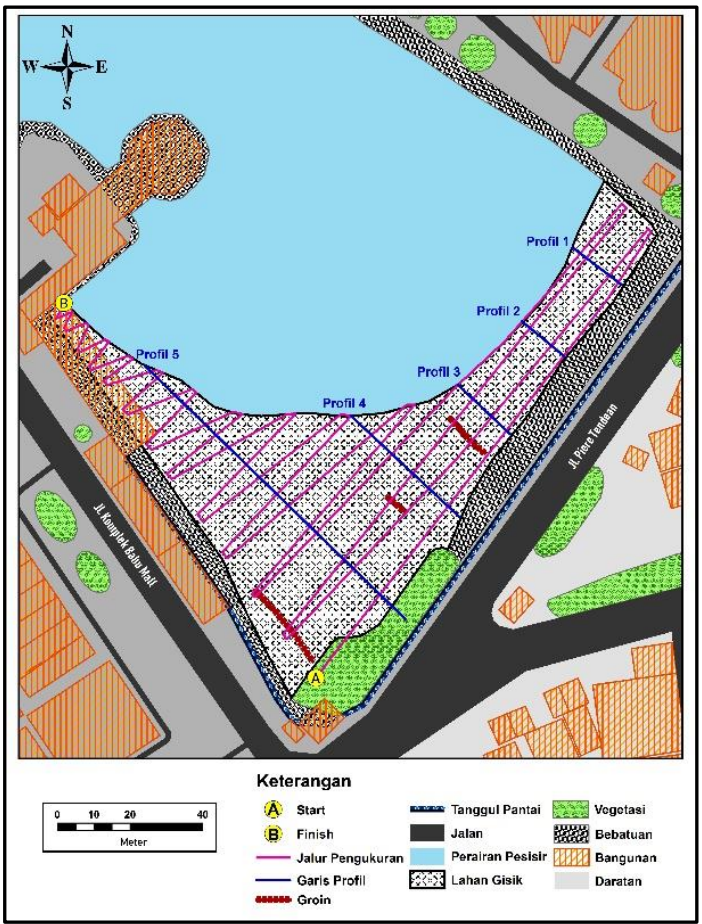

Gambar 2. Sketsa Lahan Gisik Lokasi Penelitian.

Pengumpulan data dilakukan pada tanggal 9 Februari 2020 dan untuk determinasi kemiringan lereng gisik diawali dari lahan bagian Barat Daya ke arah Timur Laut dan balik lagi ke arah Barat Daya sampai pada batas surut terendah dengan menggunakan alat bantu pengukur kemiringan lereng (profiler). Alat bantu ini telah digunakan dalam beberapa penelitian sebelumnya (Supit, 2000; Langie, 2001; Kairupan ,2002, dan Sapsuha, 2019).

Profiler dirakit menggunakan dua tonggak sejajar yang dihubungkan dengan tali sepanjang 1 meter dan memiliki skala sudut. Data utama yang diperoleh adalah sudut yang terbentuk dan terbaca pada skala sudut (busur derajat) akibat dari perbedaan ketinggian antara dua tonggak yang didirikan pada permukaan lahan gisik. Penggunaan peralatan ini dilakukan dengan cara mendirikan kedua tonggak tegak lurus pada permukaan lahan gisik, dimana perbedaan ketinggian menyebabkan tali membentuk sudut yang dapat dilihat nilainya pada skala sudut. Tegak lurusnya kedua tonggak pada permukaan lahan ditentukan berdasarkan posisi tegak lurus kedua bandul yang digantungkan pada kedua tonggak tersebut.

Pada awal pengukuran, profiler tonggak $\mathrm{A}$ dicatat nilai ketinggiannya sebagai 0 (titik kontrol) terhadap tonggak $B$ yang nilai ketinggiannya terbaca pada skala sudut (busur derajat). Nilai yang terbaca pada skala sudut dicatat. Posisi geografis kedua tonggak dicatat berdasarkan bacaan tampilan pada GPS yang diletakan pada masing-masing tonggak. Data tersebut kemudian diolah dengan menggunakan perangkat lunak Microsoft Excel dan Surfer 16.

\section{Analisis Data}

Seperti yang telah disampaikan sebelumnya, data yang diperoleh pada pengukuran dengan profiler adalah sudut yang terbentuk oleh beda tinggi antara kedua tonggak pada profiler. Jarak antara kedua tonggak (1 $\mathrm{m}$ ) dan besarnya sudut yang terbentuk digunakan untuk mendapatkan nilai beda tinggi antara kedua tonggak. Caranya adalah dengan menerapkan kaidah trigonometri menurut Andreescu dan Feng (2005) yaitu c = Z sin $\alpha$.

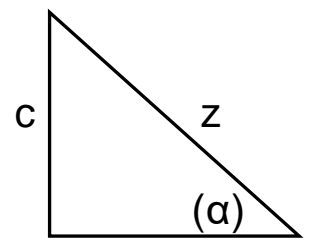


$C=$ Tinggi Lahan

$\mathrm{Z}=$ Panjang sisi miring $(1 \mathrm{~m})$

$\alpha=$ Sudut yang dibentuk sisi datar dan sisi miring

Hasil perhitungan variabel tinggi lahan (perbedaan tinggi antara kedua tonggak profiler) bersama-sama dengan posisi geografis tonggak saat pengukuran, dimasukkan ke dalam lembar kerja pada program aplikasi Surfer. Urutan pemasukan datanya adalah posisi geografis bujur sebagai data $X$, posisi geografis lintang sebagai data $Y$, dan tinggi lahan sebagai data Z. Datadata tersebut menjadi masukan untuk diolah menghasilkan relief permukaan lahan yang selanjutnya disajikan dalam bentuk peta relief permukaan lahan gisik.

Untuk keperluan mendapatkan pemahaman yang lebih baik mengenai keberadaan gisik pada lokasi penelitian, maka dibuat 5 profil pada peta relief yang dihasilkan seperti dapat dilihat dalam Gambar 2. Garis profil sedapat mungkin ditarik dari garis pantai yang merupakan bagian lahan gisik teratas (pada peta relief) ke arah laut sampai batas lebar gisik menurut penarikan garis profil. Jarak antar profil, sedapat mungkin dibuat dengan spasi yang sama.

Profil kemiringan lereng nantinya dapat berupa gambar tampilan lereng, maupun data yang dapat digunakan untuk menghitung besaran kemiringan lereng dengan menerapkan analisis regresi untuk menuntukan koefisien regresi (dinyatakan dalam \%) dari hubungan antara ketinggian permukaan lahan (Y) dan jaraknya dari garis pantai (X). Besaran panjang lereng profil gisik dan kemiringan lerengnya selanjutnya diklasifikasikan menurut Sunarto (1991).

\section{HASIL DAN PEMBAHASAN}

\section{Hasil}

\section{Morfometri Gisik}

Menggunakan perangkat lunak Surfer, peta relief permukaan lahan gisik dapat ditunjukkan seperti pada Gambar 3. Bersumber dari hasil pengolahan data yang diperjelas dengan visualisasi pada Gambar 3, luas lahan gisik Sario Kota Manado yang terukur berdasarkan luas poligon peta relief adalah $422,69 \mathrm{~m}^{2}$. Panjang lahan gisik sebesar 134,44 m dan lebar lahan pada bagian Barat Daya (terhitung dari vegetasi) adalah 123,07 m, sedangkan pada bagian Timur Laut adalah $18,63 \mathrm{~m}$.

Perbedaan lebar lahan gisik yang terbentuk pada lokasi penelitian dapat jelas dilihat pada peta relief yang dihasilkan. Lahan gisik pada bagian Barat Daya lebih lebar dibanding lahan gisik pada arah berlawanannya yaitu pada bagian Timur Laut. Walaupun demikian, sekilas tampak bahwa keseluruhan lahan gisik di bagian atas memiliki perubahan kontur dari bagian garis pantai ke arah laut dengan perubahan elevasi yang memiliki kemiripan. Hal tersebut ditunjukkan dengan perubahan elevasi kontur (Gambar 3) yang menampilkan adanya kemiripan. Kontur elevasi berubah menjadi lebih jarang yaitu dimulai pada bagian bawah lahan gisik Barat Daya. 


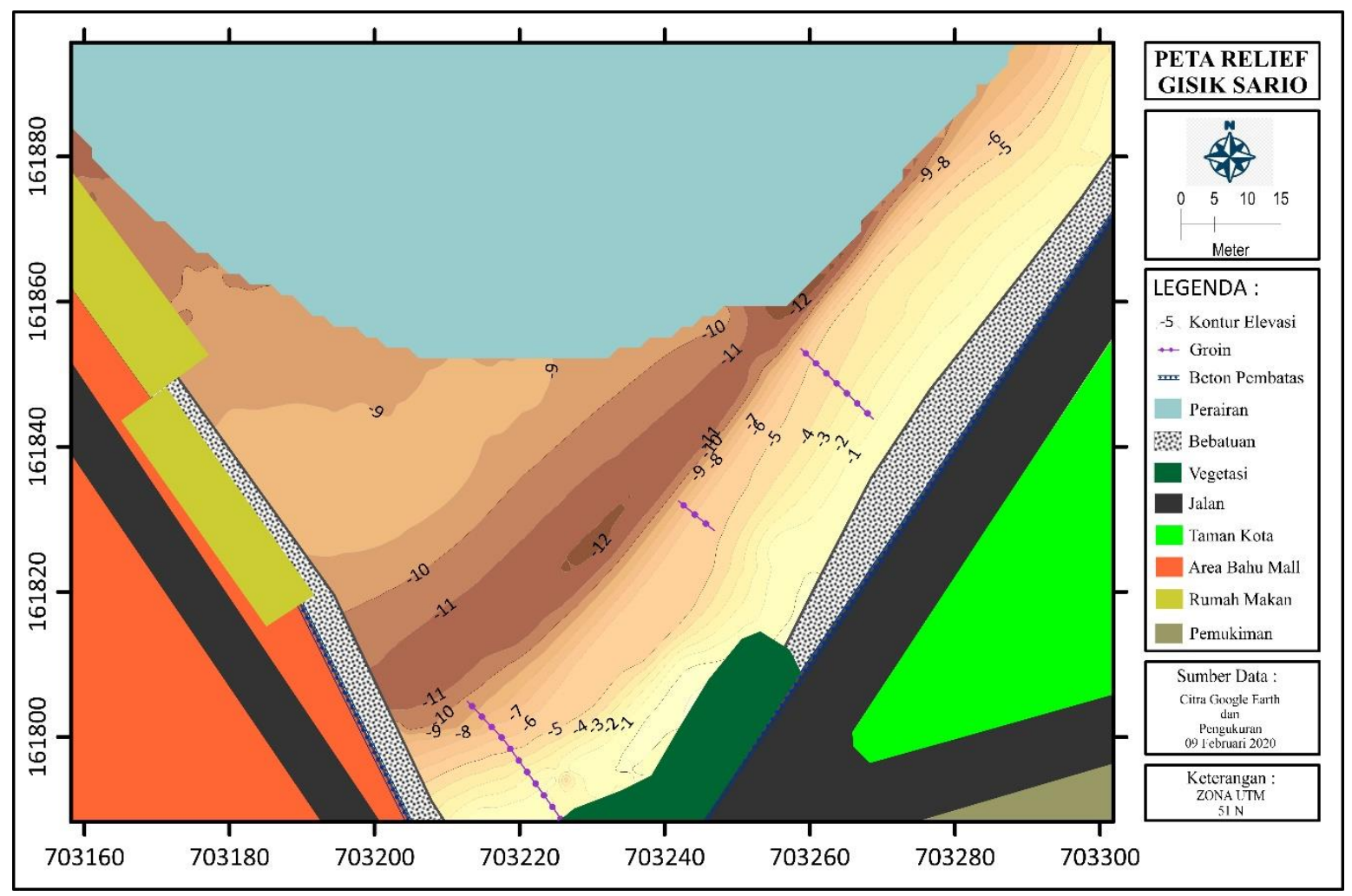

Gambar 3. Peta Relief Gisik Sario Kota Manado

\section{Profil dan Klasifikasi Kemiringan Lereng}

Kemiringan lereng pada setiap profil (dari profil 1 sampai profil 5) ditampilkan secara parsial. Hal tersebut dilakukan karena perubahan elevasi pada lahan gisik menunjukkan adanya perubahan pada bagian-bagian tertentu pada setiap profil gisik. Pengolahan data untuk mendapatkan kriteria kemiringan lereng pada bagian-bagian tertentu pada setiap profil, dilakukan dengan melihat kecenderungan perubahan elevasi pada profil yang bersangkutan (Gambar 4 sampai 9).

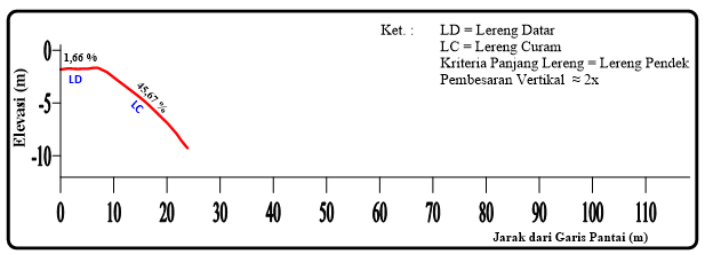

Gambar 4. Tampilan Lereng Pada Profil 1.

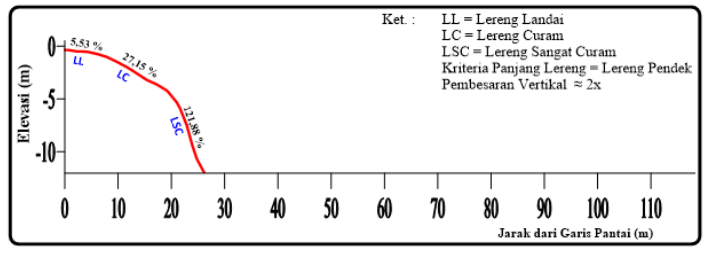

Gambar 5. Tampilan Lereng Pada Profil 2.

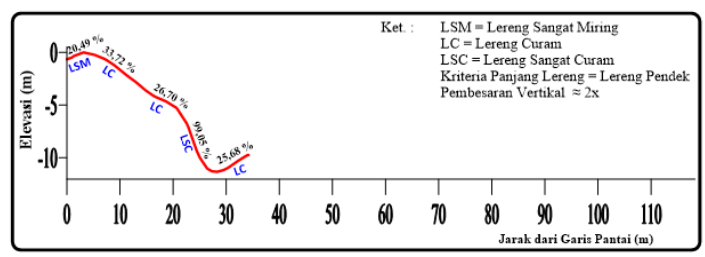

Gambar 6. Tampilan Lereng Pada Profil 3.

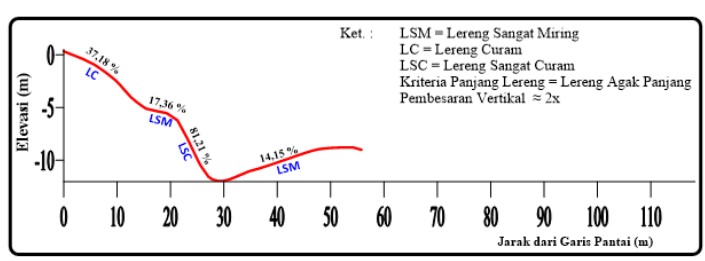


Gambar 7. Tampilan Lereng Pada Profil 4.

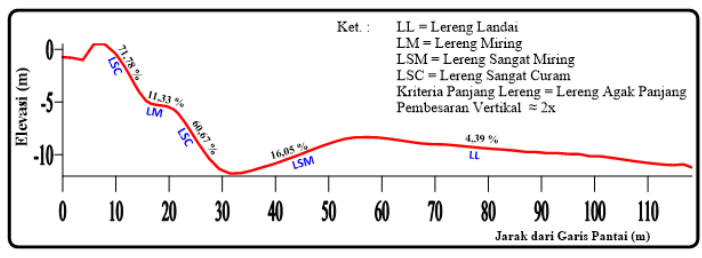

Gambar 8. Tampilan Lereng Pada Profil 5.

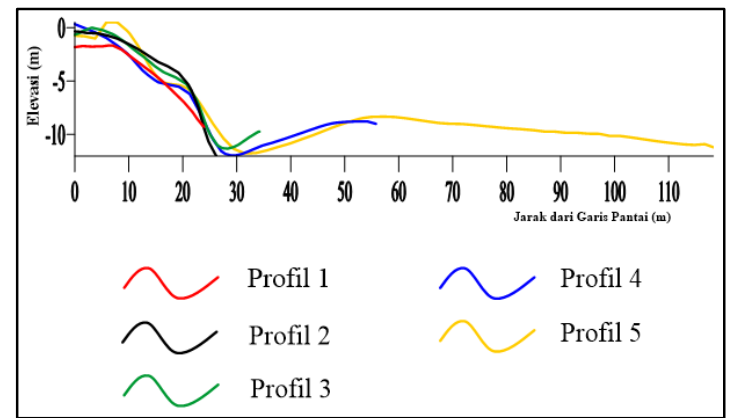

Gambar 9. Tumpang Susun Profil Gisik 1 -5 .

Keberadaan gisik di pantai Sario tampil beragam dalam hal kemiringan lereng pada bagian-bagian tertentu dan konfigurasi lekukan permukaan lahannya. Perbedaan juga dengan jelas dapat dilihat dari panjang lereng gisik yang terdedah saat surut terendah, mulai dari Profil 1 sampai dengan Profil 5. Pada Tabel 2 tampak bahwa semakin ke arah Barat Daya, lereng profil gisik semakin panjang. Bagian atas lahan gisik menampilkan adanya gundukan pada beberapa profil sementara profil lainnya tidak (Gambar 4 - 9). Pada Profil 1, gundukan hanya berupa bagian yang datar, sedangkan pada Profil 3 dan 5 gundukan terbentuk seperti bukit kecil. Pada Profil 2 dan 4, tidak tampak adanya pembentukan gundukan gisik. Hasil tumpang susun seluruh profil yang ditampilkan pada Gambar 9 memperlihatkan bagian atas gisik yang memiliki elevasi terendah adalah di Profil 1 sedangkan yang memiliki elevasi tertinggi adalah di Profil 2. Hasil tumpang susun ini juga memperlihatkan bahwa gundukan gisik yang terbentuk pada Profil 5 , kedudukannya sedikit maju ke arah laut.

Bagian muka gisik menampilkan kemiringan yang beragam, mulai dari lereng yang terklasifikasi curam sampai sangat curam. Muka gisik yang memiliki lereng yang terklasifikasi curam, tampak pada Profil $1-4$, sedangkan pada Profil 5 bagian ini terkriteria sebagai lereng sangat curam.

Keberadaan serokan dan rabung gisik pada permukaan lahan yang ditelaah bervariasi keberadaannya di setiap profil. Serokan dan rabung gisik tidak tampak keberadaannya di gisik Profil 1. Pada Profil 2 lekukan serokan dan rabung gisik mulai menunjukkan tanda terbentuknya, dan pada Profil 3 lekukannya semakin tampak. Pembentukan serokan dan rabung gisik semakin tampak pada Profil 4 dan 5 , sekalipun dengan serokan yang tidak terlalu dalam.

Pembentukan gosong pada bagian bawah lahan gisik yang terdedah saat surut terendah, dapat secara jelas terlihat terjadi pada Profil 5. Tanda-tanda terbentuknya gosong, sebenarnya sudah mulai tampak dari ujung gisik ke arah laut pada Profil 3. Pembentukan gosong tersebut semakin tampak pada Profil 4, dan lebih sempurna terbentuk pada Profil 5. Gosong yang terbentuk tampak tidak simetris, memiliki lereng sangat miring pada bagian gisik yang menghadap ke arah daratan, dan melandai ke arah laut. 
Tabel 1. Panjang Garis Profil 1 sampai 5

\begin{tabular}{|c|c|c|c|c|c|}
\hline \multirow{2}{*}{ No } & \multirow{2}{*}{ Profil } & \multicolumn{2}{|c|}{ Koordinat UTM } & Panjang & Kriteria Panjang \\
\cline { 3 - 4 } & & Longitude & Latitude & Lereng $(\mathrm{m})$ & Lereng Gisik \\
\hline 1 & Profil 1 & 161872,9 & 703301,5 & 23,88 & Pendek \\
\hline 2 & Profil 2 & 161854,5 & 703287,7 & 26,19 & Pendek \\
\hline 3 & Profil 3 & 161835,6 & 703273,8 & 34,21 & Pendek \\
\hline 4 & Profil 4 & 161814,8 & 703258,3 & 55,78 & Agak Panjang \\
\hline 5 & Profil 5 & 161797,4 & 703245,1 & 118,29 & Agak Panjang \\
\hline
\end{tabular}

\section{Pembahasan}

Pembentukan bagian muka gisik pada lahan yang ditelaah, mencerminkan kerja faktor hidro-oseanografi khususnya gelombang pada lahan tersebut. Saat pasang tertinggi, hampir seluruh lahan gisik tertutup oleh air laut (Gambar 10). Saat air laut surut, gelombang akan bekerja melalui hempasan (swash) dan luncuran balik air laut (backswash) pada permukaan lahan gisik, membentuk muka gisik yang hampir seragam ditunjukkan pada seluruh profil yang berlereng curam.

Terbentuknya puncak-puncak (crest) pada permukaan lahan gisik memberikan petunjuk bahwa proses yang sementara berlangsung pada bagian permukaan gisik adalah deposisi, sebaliknya saat periode erosi terjadi puncak-puncak tersebut akan hilang. Menurut Ruiz et al. (2020), pembentukan gundukan dan posisi puncak-puncak gisik relatif berhubungan dengan level pasang surut air laut serta posisi gelombang pecah dan batas hempasan gelombang. Lebih lanjut dijelaskan, tampilan seperti puncak-puncak akan terbentuk di permukaan gisik selama periode deposisi sedimen dan akan menjadi datar atau menghilang selama periode erosi. Pada lahan gisik yang ditelaah, puncak-puncak pada permukaan lahan gisik dapat dilihat keberadaannya, sekalipun dengan tingkat timbulan yang berbeda. Keberadaan puncak-puncak tersebut, semakin tampak pada profil gisik yang berada di bagian Barat Daya, yaitu pada Profil 4 dan 5. Hal ini memberikan petunjuk mengenai deposisi sedimen yang lebih intensif terjadi pada gisik di bagian ini.

Deposisi sedimen pada lahan gisik yang ditelaah tampaknya lebih intensif terjadi pada gisik di bagian Barat Daya. Beberapa bukti yang dapat menguatkan hal ini adalah di samping puncak-puncak terjadi pada permukaan lereng gisik, akumulasi sedimen tampak terjadi pada bagian ini. Bagian gisik yang lebih dahulu terdedah saat air laut mulai surut adalah pada bagian ini (Gambar 10). Gisik yang terdedah saat air surut dengan lereng terpanjang, juga ditunjukkan oleh profilprofil pada bagian ini (terutama Profil 5). Bukti yang lain adalah terbentuknya gosong pada bagian bawah lahan gisik. Keberadaan ini dapat terjadi apabila deposisi sedimen dalam jumlah yang cukup besar terjadi di tempat itu.

Suplai sedimen yang terjadi dalam jumlah lebih besar pada kawasan gisik di bagian Barat Daya tampaknya merupakan hasil kerja arus susur pantai. Kedudukan lahan gisik dan konfigurasi penempatan berbagai artificial di sekitar lahan gisik menciptakan pola refraksi dan difraksi gelombang yang menentukan terhadap pembentukan sudut saat gelombang pecah di garis pantai. 


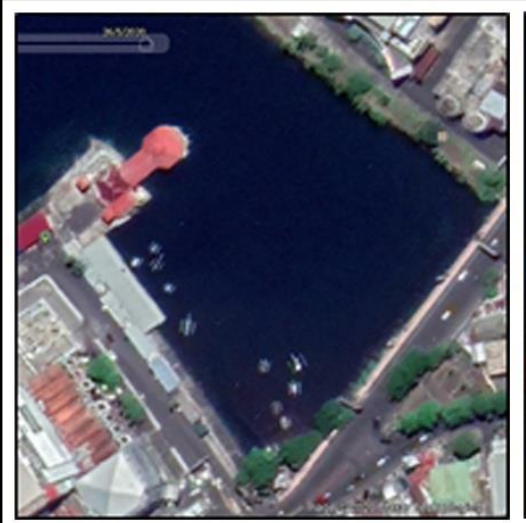

(A)

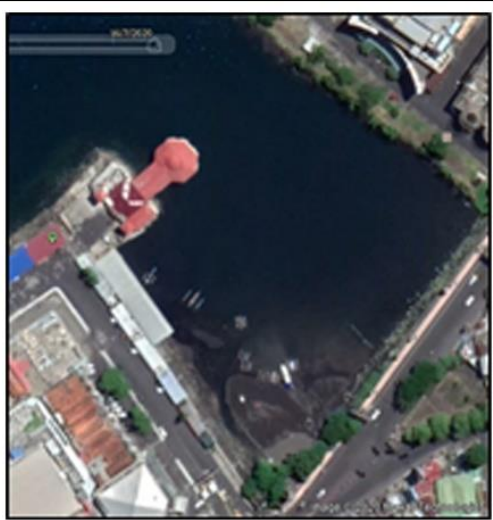

(B)

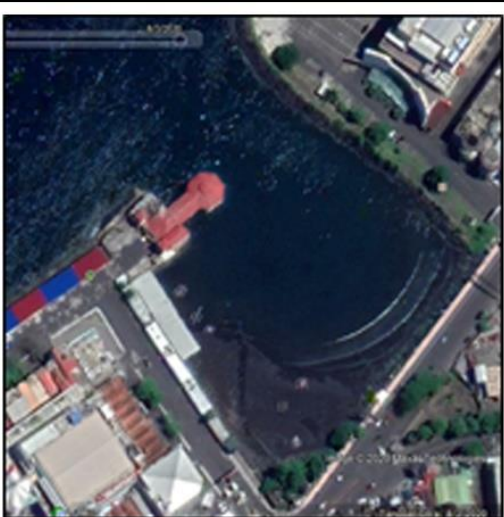

(C)

Gambar 10. Lahan Gisik Sario Pada Berbagai Kondisi Pasut. (A) Saat pasang Tertinggi, (B) Saat Air Laut Mulai Surut, (C) Saat Air Surut. (Sumber: Citra Google Earth)

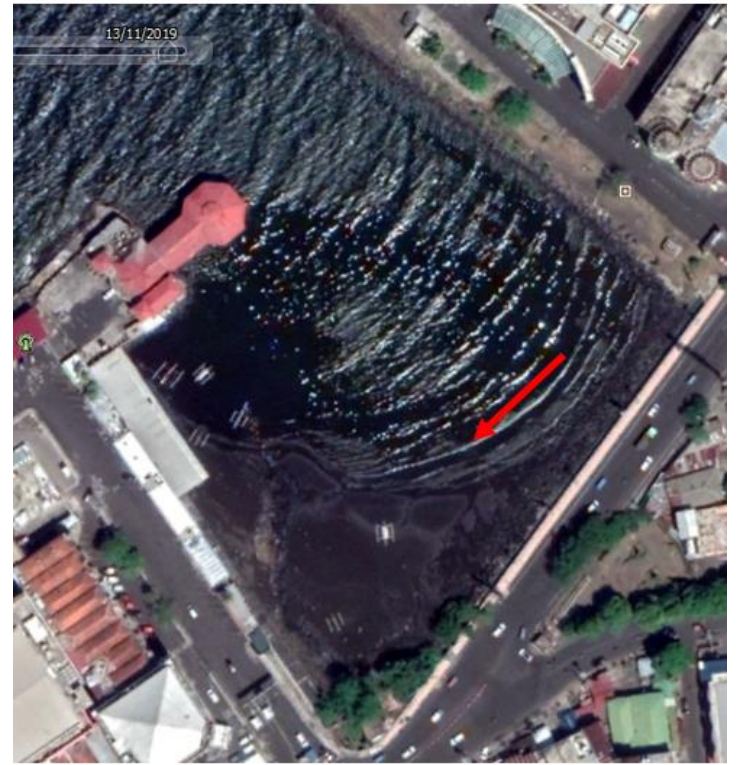

Gambar 11. Pembentukan Sudut Saat Gelombang Pecah di Garis Pantai, Panah Merah memperlihatkan Arah Pergerakan Arus Susur Pantai. (Sumber: Citra Google Earth).
Refraksi dan difraksi yang terjadi pada gelombang yang memasuki kawasan ini, mengakibatkan gelombang datang ke garis pantai akan membentuk sudut dengan bukaan ke arah Barat Daya (Gambar 11). Arus susur pantai terbentuk apabila gelombang datang membentuk sudut dengan garis pantai. Arah arus susur pantai akan menuju ke bagian bukaan sudut yang terbentuk. Arus ini merupakan penyebab utama terjadinya transpor sedimen di sepanjang pantai. Hal ini juga yang mengakibatkan pada gisik di bagian Barat Daya, deposisi sedimen lebih intensif terjadi dibanding bagian lainnya, karena suplai sedimen berada dalam jumlah yang lebih besar pada bagian ini.

\section{KESIMPULAN}

Lahan gisik Sario Kota Manado
telah ditelaah berdasarkan hasil
pengolahan terhadap data hasil
pengukuran elevasi secara terinci. Sejauh
yang dihasilkan dari serangkaian
penelitian dalam tahap studi ini, beberapa


kesimpulan dapat dikemukakan sebagai berikut :

1) Gisik terdedah saat surut yang terbentuk pada kawasan pantai ini semakin membesar dari arah Timur Laut sampai ke arah Barat Daya. Berdasarkan kriteria panjang lereng gisik yang terbentuk, gisik yang berada di bagian Timur Laut terkriteria sebagai lereng pendek, sementara yang di bagian Barat Daya terkriteria sebagai Lereng agak panjang.

2) Kemiringan lereng pada bagian muka gisik berdasarkan profil yang dibuat umumnya berupa lereng curam, kecuali pada profil yang berada di bagian Barat Daya (Profil 5) terkriteria lereng sangat curam. Bagian-bagian yang umumnya terbentuk pada permukaan lahan gisik seperti serokan dan rabung gisik, tampilannya semakin dapat teridentifikasi pada profil gisik yang semakin ke arah Barat Daya. Pada profil di bagian paling Barat Daya ini juga terbentuk gosong pada bagian bawah lahan gisik. Semua fakta ini memberikan petunjuk bahwa pada kawasan gisik di pantai Sario, deposisi lebih intensif terjadi pada area gisik di bagian Barat Daya.

\section{DAFTAR PUSTAKA}

Andreescu, T. and Z. Feng, 2005. 103 Trigonometri Problems : From the Training of the USA IMO Team. Birkhauser Boston, USA. 214 hal.

Gross M.G., 1993 Oceanography. A View of Earth. Sixth Edition.

Kairupan A.A.F. 2002. Proses Pembentukan Lahan Gisik Di Pantai Kelurahan Batulubang Kecamatan Bitung Selatan. Skripsi, Tidak Dipublikasikan.
FPIK Universitas Sam Ratulangi, Manado. 71 hal.

Langie, P.E., 2001. Identifikasi Proses Pembentukan Lahan Gisik Di Selat Lembeh Bagian Barat. Skripsi. FPIK, Universitas Sam Ratulangi, Manado. 69 hal.

Pethick, J., 1997. An Introduction to Coastal Geomorphology. Edward Arnold. London. 259 hal.

Ruiz, A.L., Sanchez M.O., and Losada M,A., 2020. Mixed Sand and Gravel Beaches. In: Sandy Beach Morphodynamics. Ed: Jackson D.W.T. and Short A.D. Elsevier Ltd. Amsterdam, Netherlands. Hal $317-341$.

Sapsuha, I., 2019. Morfologi Gisik Di Kawasan Pantai Tanjung Merah Kota Bitung. Skripsi. FPIK, Universitas Sam Ratulangi, Manado. 114 hal.

Supit, A.A.G., 2000. Morfologi Gisik Di Kawasan Wisata Tasik Ria Mokupa. Skripsi. FPIK, Universitas Sam Ratulangi, Manado. 76 hal.

Williams, A. and Micallef, A., 2009. Beach Management, Principles and Practice. Earthscan. United Kingdom. 446 hal. 